\title{
ÜMINIS RESPIRACINIS DISTRESO SINDROMAS IR KORTIKOSTEROIDŲ VARTOJIMAS VAIKAMS
}

\author{
Sigitas Filipauskas, Gintarè Gečaitė \\ Lietuvos sveikatos moksly universiteto Medicinos akademija, Medicinos fakultetas
}

Raktažodžiai: ŪRDS (ūminis respiracinis distreso sindromas), kortikosteroidai, vaikai, pediatrija.

\begin{abstract}
Santrauka
Darbo tikslas buvo ịvertinti, susisteminti ir išanalizuoti mokslinejje literatūroje pateikiamus duomenis apie vaikų respiracinio distreso sindromo metu vartojamus kortikosteroidus. Šioje sistemineje apžvalgoje išanalizuotas 21 viso teksto straipsnis. Remiantis atrinktų straipsnių rezultatų duomenimis, galime teigti, kad yra indikacijų, kai steroidų poveikis gali būti naudingas: uždegimo gydymas ankstyvuoju ŪRDS periodu, siekiant sumažinti plaučiu pažeidimą, gydyti su liga susijusį kortikosteroidų nepakankamumą, gydant dirbtinès plaučių ventiliacijos uždegiminius padarinius bei gydant ŪRDS vaikui, sergančiam kitomis lètinèmis kvėpavimo takų ligomis, tačiau tai neturètų būti rutininè terapija.
\end{abstract}

\section{Ivadas}

Vaikų ŪRDS yra heterogeninis procesas, sukeliantis sunkų ūminị plaučiu sužalojimą. ŪRDS yra sudètingas darinys, sukeliantis didelę žalą ir padidejjusį sveikatos priežiūros išteklių naudojimą [1]. Nepaisant daugybės klinikinių ventiliacijos valdymo pasiekimų, ŪRDS ir toliau yra vienas iš sunkiausių ligos procesų intensyvios priežiūros pacientams. Nors patofiziologiniai panašumai galimi ịvairaus amžiaus žmonèms, vaikų intensyviosios priežiūros bendruomenẻ per pastaruosius kelerius metus pripažino, kad naujagimiams būdingi išskirtiniai bruožai, reikalingi ypatingo dèmesio [2]. Visuomenès sveikatos požiūriu, ŪRDS laikomas retu sindromu. Vienas JAV tyrimas atskleide, kad ŪRDS sudaro 12,8 atvejo 100000 vaiku per metus [3]. Kitame Australijoje bei Naujojoje Zelandijoje atliktame tyrime nustatyta, kad serga 2,95 iš $100000<16$ metų asmenų. Kiekvienais metais pasaulio intensyviosios terapijos skyriuose tūkstančiai vaikų miršta dèl ŪRDS [4]. Deja, toliau trūksta tiesioginès, patikrintos ir būtinai reikalingos veiksmingos terapinès intervencijos.
Atsižvelgiant ị biologinị pagrindimą, kortikosteroidai buvo plačiai naudojami klinikų gydytojų ir daugelio laikomi naudingais gydyti ŪRDS, tačiau trūksta ịrodymų, kad juos būtų galima plačiai naudoti, yra tik užuominų apie jų naudojimą netinkamai apibrèžtuose ŪRDS pogrupiuose [5].

Darbo tikslas - išanalizuoti bei aptarti ịrodymais pagrịstas sąsajas tarp üminio respiracinio distreso sindromo bei steroidų vartojimo vaikų populiacijoje.

\section{Tyrimo medžiaga ir metodai}

Taikyta sisteminè mokslinès literatūros bei dokumentu apžvalga ir analizė. Duomenų buvo ieškoma PubMed, Google Scholar, Up ToDate, Wiley bei Cochrane duomenu bazėse. Visateksčiai straipsniai atrinkti, jei jų pavadinimas, santrauka ar reikšminiai žodžiai nurode, kad tyrimas tinkamas šiai apžvalgai. Pasirinktos tik anglų kalba skelbtos publikacijos, pasirodžiusios pastarujų 13 metų laikotarpiu. Vartoti anksčiau nurodyti raktažodžiai. Atrinktas ir apibendrintas 21 straipsnis.

\section{Rezultatai}

ŪRDS yra klinikinis sindromas, atsirandantis dèl alveolinio epitelio ir endotelio pralaidumo barjero, nesusijusio su kardiogenine plaučių edema, pažeidimo. Sužalojimas galimas tiesiogiai ị alveolių epitelị (t.y. pneumonija, ịkvèpti toksinai ir kt.), arba netiesiogiai kapiliarų endoteliui dèl sisteminio uždegimo, tokio kaip sepsis, ar pankreatitas [6]. Sutrikus alveolinio endotelio barjerui, alveolèse susikaupia daug baltymų turinčio skysčio. Tada slopinamas uždegimas ir krešèjimas, dèl kurio sutrinka limfos nutekejjimas [7]. Padidèjęs alveolių kapiliarų membranos pralaidumas lemia baltymingą neutrofilinį eksudatą, intersticinę ir alveolinę edemą bei hialino membranas. Dél šių patologinių anomalijų pablogèja dujų apykaita ir sumažèja plaučiu fiziologinè talpa. Ši plaučių patologija atsiranda nustatant uždegimą, didelį leukocitų ir trombocitų aktyvumą bei nekontroliuojamą krešèjimo kelių aktyvavimą. Kliniškai šie alveoliniai pokyčiai lemia restrikcinę plaučių ligą, kuriai būdinga hipok- 
semija, rentgenografiniai patamsèjimai, sumažèjęs funkcinis liekamasis pajègumas ir padidejęs fiziologinis negyvasis plotas. Uždegimas paprastai praeina per kelias savaites, bet gali išsivystyti ir fibrozė [6]. Žinoma, kad dažniausia ŪRDS priežastis vaikams yra virusinè kvėpavimo takų infekcija, nors ŪRDS gali būti siejama su daugeliu kitų esminių būklių, ìskaitant pneumoniją, sepsị, traumas, nudegimus, pankreatitą ir kraujo perpylimą [7].

Negebejjimas sureguliuoti uždegiminio mediatoriaus gaminimo, lemia netinkamą alveolių ir kapiliarų membranos atkūrimą ir sutrikusius dujų mainus [15]. ŪRDS metu išskiriami citokinai stimuliuoja kortizolio sintezę ir veikimą, tiesiogiai veikdami pagumburio-hipofizès-antinksčio aši ir gliukokortikoidų receptorius (toliau - GR). Tyrimai rodo, kad ŪRDS gali būti susijęs su kortikosteroidų, siejamų su kritine liga, nepakankamumu.Tai apibrèžiama kaip nepakankamas paciento ligos kortikosteroidų aktyvumas, atsirandantis sumažèjus antinksčių steroidų gamybai dèl disfunkcijos bet kuriame pagumburio-hipofizès-antinksčių ašies taške arba dèl audinių atsparumo gliukokortikoidams [16]. Steroidai neutralizuoja beveik kiekvieną uždegiminès kaskados žingsnị, moduliuodami imuninị atsaką. Jie sumažina citokinų gamybą ir palengvina makrofagų migraciją slopinančio faktoriaus gamybą. Papildomas steroidų poveikis prisideda prie homeostazès palaikymo sunkios ligos metu. Širdies ir kraujagysliu sistemos palaiko kraujagyslių tonusą, stiprina katecholaminu kraujagysles sutraukiantị poveikị ir mažina azoto oksido gamybą. Tai skatina skysčių pasiskirstymą kraujagyslèse [17].

Pripažindama, kad vaikų ŪRDS skiriasi nuo suaugusiujjų, tarptautinė ekspertų grupė sušaukè vaikų ūminio plaučių sužalojimo konsensuso konferenciją (toliau - PALICC), kad nustatytų naujas vaikų ŪRDS apibrezžtis ir gaires [8]. 2015 $\mathrm{m}$. PALICC apibréžtis išsiplète ir reikalaujama ị radiografini reikalavimą įtraukti visus naujus parenchiminius infiltratus. Papildomi pagrindiniai ŪRDS apibrěžimo skirtumai apima impulsų oksimetrijos naudojimą, siekiant išvengti nepakankamo ŪRDS paplitimo vaikams ịvertinimo, jei nëra arterinio kraujo deguonies matavimų, o $\mathrm{SpO}_{2} \leq 97$ proc., deguonies indekso (toliau - OI) $\left[\left(\mathrm{FiO}_{2} \times\right.\right.$ vidutinis kvejpavimo taku slègis $\times 100) / \mathrm{PaO}_{2}$ ] ir prisotinimo deguonimi indekso (OSI) $\left[\left(\mathrm{FiO}_{2} \times\right.\right.$ vidutinis kvėpavimo takų slègis $\left.\left.\times 100\right) / \mathrm{SpO}_{2}\right]$ panaudojimas, o ne $\mathrm{PaO}_{2} / \mathrm{FiO}_{2}(\mathrm{P} / \mathrm{F})$ santykis hipoksemijai ivertinti [8].

Vaikų ŪRDS kriterijai [8]:

- Ūmi pradžia per 7 dienas po klinikinio pažeidimo.

- Naujų (vienpusių ar dvipusių) infiltratų krūtinès ląstos (rentgenografijos ar kompiuterinès tomografijos) išvados, atitinkančios ūmią parenchiminę ligą.

- Edema nevisiškai paaiškinta skysčių pertekliumi ar širdies nepakankamumu.
- Gali pasireikšti kaip nauja ūmi plaučių liga, nustatant lètinę plaučių ir (arba) širdies ligą.

- Išimtys: perinatalinè plaučių liga.

Kvèpavimo nepakankamumas yra dažniausia vaikų, patekusių i vaikų intensyviosios terapijos skyrių (toliau -VITS), mirties priežastis [9]. ÜRDS sudaro 1-10 proc. VITS pacientų. ŪRDS mirtingumas labai skiriasi, greičiausiai priskirtinas prie skirtingų šalutinių ligų ir skirtingos etiologijos [10]. ŪRDS mirties priežastys ịvairios, atsižvelgiant ị heterogeninę ligos proceso etiologiją. Dideliame retrospektyviame tyrime neurologinis nepakankamumas ir daugelio sistemų organų nepakankamumas buvo pagrindinès ankstyvosios ir vèlyvosios mirties priežastys ir tik maža dalis mirčių buvo priskirtos prie sunkiai gydomos hipoksemijos. ŪRDS atveju ankstyvosios mirties priežastys pirmiausia yra dèl neurologinio nepakankamumo, o vèlesnès labiau tikètinos dèl sunkiai gydomos hipoksemijos [11]. Nors vaikų ŪRDS mirtingumas per pastaruosius kelis dešimtmečius sumažejo ir yra mažesnis, nei suaugusiujų, kuris svyruoja nuo 35 iki 46 proc., vis dèlto vaikų mirtingumas tebèra reikšmingas. Siekiant dar labiau sumažinti mirtingumo naštą, labai svarbu patobulinti identifikavimą, rizikos stratifikavimą ir tikslingą valdymą [12].

Dèl ŪRDS pasireiškiantis uždegimas paskatino domètis steroidų vartojimu uždegimui gydyti. Nepaisant ịrodymų, kad kortikosteroidai pagerina suaugusiujų̧, sergančių ŪRDS, plaučių ir kitų organų funkcijas, veiksmingumas mažinant mirtingumą (35,8proc. suaugusiujų ir 18 proc. vaikų) vis dar ginčijamas keliuose randomizuotuose klinikiniuose tyrimuose ir metaanalizėse [19]. Kortikosteroidai turi stiprų poveikį uždegimui, įskaitant kelių imuninių ląstelių, tokių kaip T ir B tipo limfocitų, monocitų, neutrofilų, eozinofilų skaičiaus ir funkcijos sumažèjimą uždegimo vietose. Kortikosteroidai sumažina citokinų ir eikozanoidų gamybą, padidina makrofagų migraciją slopinančio faktoriaus gamybą. Klinikiniai ir eksperimentiniai duomenys rodo, kad ŪRDS dažnai yra susijęs su kortikosteroidų nepakankamumu. Šiai būklei būdingas aktyvuotų gliukokortikoidų receptorių negebejjimas sureguliuoti uždegiminių citokinų transkripcijos, nepaisant aukšto kortizolio kiekio kraujyje.

G. Meduri ir kt. $2018 \mathrm{~m}$. atliktoje metaanalizejje įvertino 9 atsitiktinių imčių kontroliuojamus suaugusiujų ŪRDS gydymo nuo mažų iki vidutinių dozių tyrimus. Nustatyta, kad gydymas steroidais yra saugus ir mažina dirbtinès ventiliacijos trukmę, intensyviosios terapijos priežiūrą, paciento laiką gydymo įstaigoje bei mirtingumą [13]. Yra keletas atvejų, kai steroidų poveikis gali būti naudingas ŪRDS sergantiems pacientams: uždegimo gydymas ankstyvuoju ŪRDS periodu, siekiant sumažinti plaučių pažeidimą; gydyti su liga susijusį kortikosteroidų nepakankamumą; gydyti dirbtinès 
plaučių ventiliacijos uždegiminius padarinius [19]. Iki šiol neatlikta didelių, atsitiktinių imčių, vaikų ŪRDS gydymo kortikosteroidais kontroliuojamų tyrimų. Mažos apimties vaikų atsitiktinès atrankos būdu kontroliuojamas tyrimas, tiriantis metilprednizolono vartojimą ŪRDS metu, nerado jokio skirtumo tarp mirtingumo, dirbtinès ventiliacijos trukmès, VITS praleisto laiko, gydant steroidais [14]. B. Drago it kt. atliktame randomizuotame dvigubai aklame, placebu kontroliuojamame bandomajame metilprednizolono tyrime dalyvavo 35 ŪRDS pacientai. Pacientai vartojo placebą arba metilprednizoloną pirmąsias 72 dirbtinès plaučių ventiliacijos valandas. Tyrimas neparode rezultatų skirtumo, tačiau jis atskleidè, kad ateityje būtų galima atlikti didesnị ir tikslesnị tyrimą [14]. Dèl plataus veikimo ị keletą organizmo sistemų, pacientams gali pasireikšti daugialypis šalutinis poveikis. Pagrindinès problemos yra kraujavimas iš virškinamojo trakto, imuninés sistemos slopinimas, dèl kurio gali sustiprèti esamoji infekcija, metabolinis poveikis, toks kaip hiperglikemija, natrio chlorido, vandens susilaikymas ir kalio praradimas, psichinis poveikis, toks kaip nemiga, psichozė ir delyras. Šis poveikis gali būti kliniškai reikšmingas pacientams, sergantiems sunkiu ŪRDS [18]. Grupès, kurioms greičiausiai naudingas kortikosteroidų vartojimas gydant vaikų ŪRDS, būtų tos, kurių pagrindinès būklès gali reaguoti ị steroidus, pavyzdžiui, astma, difuzinis alveolių kraujavimas, pneumocistinè pneumonija, radiacinis pneumonitas ir kitos lètinès obstrukcinès plaučiu ligos [20].

Pediatrijoje trūkstant aiškiu ịrodymų, PALICC rekomenduoja nevartoti kortikosteroidų kaip ịprastinès ŪRDS terapijos, kol laukiama tolesnių tyrimų su konkrečiomis populiacijomis. Tinkamos rekomendacijos, dèl kurių pacientams būtų naudingas metilprednizolono vartojimas ŪRDS atveju, yra labai svarbios, norint užtikrinti, kad gydymo nauda būtų didesnè už kortikosteroidų vartojimo riziką, įskaitant imunosupresiją, hospitalines infekcijas, hiperglikemiją, neuromiopatiją ir kitus funkcinius sutrikimus.

\section{Išvados}

1. Yra indikacijų, kai steroidų poveikis gali būti naudingas: uždegimo gydymas ankstyvuoju ŪRDS periodu, siekiant sumažinti plaučių pažeidimą, gydyti su liga susijusi kortikosteroidų nepakankamumą, gydant dirbtinès plaučių ventiliacijos uždegiminius padarinius bei ŪRDS vaikui, sergančiam kitomis lėtinėmis kvėpavimo takų ligomis.

2. Svarbiausias šalutinis kortikosteroidų poveikis, kuris kelia didžiausią susirūpinimą, yra kraujavimas iš virškinamojo trakto, imuninès sistemos slopinimas, metabolinis, psichinis poveikis.

3. Nors nèra pakankamai ịrodymų, kad būtų galima rekomenduoti ịprastinị terapinị kortikosteroidų vartojimą vaikų
ŪRDS, reikalingi tolesni tyrimai, siekiant tinkamai nustatyti pacientų populiaciją, vartojimo laiką ir dozavimo schemą.

\section{Literatūra}

1. Carlton EF, Flori HR. Biomarkers in pediatric acute respiratory distress syndrome. AnnTransl Med 2019;7(19):505. https://doi.org/10.21037/atm.2019.09.29

2. Cornfield DN. Acute respiratory distress syndrome in children: physiology and management. Curr Opin Pediatr 2013;25:338-43. https://doi.org/10.1097/MOP.0b013e328360bbe7

3. Zimmerman JJ, Akhtar SR, Caldwell E, et al. Incidence and outcomes of pediatric acute lung injury. Pediatrics 2009;124:87-95. https://doi.org/10.1542/peds.2007-2462

4. Erickson S, Schibler A, NumaA, et al. Acute lung injury in pediatric intensive care in Australia and New Zealand: a prospective, multicenter, observational study. Pediatr CritCare Med 2007;8:317-23. https://doi.org/10.1097/01.PCC.0000269408.64179.FF

5. Monteverde-Fernández N, Cristiani F, McArthur J, GonzálezDambrauskas S. Steroids in pediatric acute respiratory distress syndrome. AnnTransl Med 2019;7(19):508. https://doi.org/10.21037/atm.2019.07.77

6. SapruA, Flori H, Quasney MW, et al. Pathobiology of acute respiratory distress syndrome. Pediatr Crit Care Med 2015;16:S6-S22. https://doi.org/10.1097/PCC.0000000000000431

7. Heidemann SM, Nair A, Bulut Y, et al. Pathophysiology and management of acute respiratory distress syndrome in children. Pediatr Clin North Am 2017; 64:1017-1037. https://doi.org/10.1016/j.pcl.2017.06.004

8. Pediatric acute respiratory distress syndrome: consensus recommendations from the pediatric acute lung injury consensus conference. Pediatr Crit Care Med 2015;16:428-439. https://doi.org/10.1097/PCC.0000000000000350

9. Burns JP, Sellers DE, Meyer EC, et al. Epidemiology of death in the PICU at five U.S. teaching hospitals. Crit Care Med 2014; 42:2101-2108. https://doi.org/10.1097/CCM.0000000000000498

10. Quasney MW, Lopez-Fernandez YM, Santschi M, et al. The outcomes of children with pediatric acute respiratory distress syndrome: proceedings from the pediatric acute lung injury consensus conference. Pediatr Crit Care Med 2015;16:S118-S131. https://doi.org/10.1097/PCC.0000000000000438

11. Dowell JC, Parvathaneni K, Thomas NJ, et al. Epidemiology of cause of death in pediatric acute respiratory distress syndrome. Crit Care Med 2018; 46:1811-1819. https://doi.org/10.1097/CCM.0000000000003371

12. Bellani G, Laffey JG, Pham T, etal. Epidemiology, patterns of care, and mortality for patients with acute respiratory distress syndrome in intensive care units in 50 countries. JAMA 2016;315:788-800. https://doi.org/10.1001/jama.2016.0291

13. Meduri GU, Siemieniuk RAC, Ness RA, et al. Prolonged low-dose methylprednisolone treatment is highly effective in reducing duration of mechanical ventilation and morta- 
lity in patients with ARDS. J Intensive Care 2018;6(53). https://doi.org/10.1186/s40560-018-0321-9

14. Drago BB, Kimura D, Rovnaghi CR, et al. Double-blind, placebo-controlled pilot randomized trial of methylprednisolone infusion in pediatric acute respiratory distress syndrome. Pediatr Crit Care Med 2015;16:e74-e81. https://doi.org/10.1097/PCC.0000000000000349

15. Meduri GU, YatesCh. Systemic inflammation-associated glucocorticoid resistance and outcome of ARDS. Ann NY Acad Sci 2004;1024:24-53.

https://doi.org/10.1196/annals.1321.004

16. Levy-Shraga Y, Pinhas-Hamiel O. Critical illness-related corticosteroid insufficiency in children. Horm Res Paediatr 2013;80:309-17. https://doi.org/10.1159/000354759

17. Monteverde-Fernández N, Cristiani F, McArthur J, GonzálezDambrauskas S. Steroids in pediatric acute respiratory distress syndrome. Ann Transl Med 2019;7(19):508. https://doi.org/10.21037/atm.2019.07.77

18. Drozdowicz LB, Bostwick JM. Psychiatric adverse effects of pediatric corticosteroid use. Mayo Clin Proc 2014;89:817-34. https://doi.org/10.1016/j.mayocp.2014.01.010

19. Barbosa MC, Barbosa AP, Rocco PR. Corticosteroids therapy in pediatric acute respiratory distress syndrome. Rev BrasTer Intensiva 2010;22:384-94.

20. Hartmann SM, Hough C. Argument against the routine use of steroids for pediatric acute respiratory distress syndrome. Front Pediatr 2016;4:79.

https://doi.org/10.3389/fped.2016.00079

\section{ACUTE RESPIRATORY DISTRESS SYNDROME AND CORTICOSTEROIDS USE IN CHILDREN}

\section{S. Filipauskas, G. Gečaitė}

Keywords: acute respiratory distress syndrome, corticosteroids, children, pediatrics.

Summary

The aim of this study was to evaluate, systematize and analyze the data presented in the scientific literature on the use of corticosteroids in children with respiratory distress syndrome. This systematic review analyzes 21 full-text articles.Based on the results of selected articles, we can state that there are indications when steroids may be useful: treatment of inflammation in the early period of acute respiratory distress syndrome (ARDS) to reduce lung damage, treatment of disease-related corticosteroid deficiency, treatment of inflammatory effects of mechanical pulmonary ventilation and treatment of ARDS in children with other chronic respiratory diseases, but this should not be routine therapy.

Conclusions. The main side effects of corticosteroids that are of biggest concern are gastrointestinal bleeding, immunosuppression, metabolic effects, mental effects. Although there is insufficient evidence to recommend routine use of corticosteroids in pediatric ARDS, it is a therapy that requires further studies to determine the correct patient population, timing of administration, and dosing regimen.

Correspondence to: sigitas.filipauskas@stud.lsmu.lt

Gauta 2020-05-06 